\title{
Effects of Different Water Supply and Corm Planting Density on Crocin, Picrocrocin and Safranal, Nitrogen Uptake and Water Use Efficiency of Saffron Grown in Semi-Arid Region
}

\author{
Alireza KOOCHEKI*, Seyyed Mohammad SEYYEDI \\ Ferdowsi University of Mashhad, Faculty of Agriculture, Department of Agronomy, PO Box 91779, 48974 Mashhad, \\ Iran;akooch@um.ac.ir(*correspondingauthor);se.seyyedi@alumni.um.ac.ir
}

\begin{abstract}
Saffron's color, taste and odor result from the chemicals crocin, picrocrocin and safranal, respectively. Hence, in addition to quantitative yield, secondary metabolites content are known as crucial factors for a successful saffron production. Moreover, enhancing resources efficiency, especially water and nitrogen, is becoming increasingly important for agricultural improvement in arid and semi-arid regions. Thus, the effects of irrigation levels and corm planting on crocin, picrocrocin and safranal content, water use efficiency (WUE) as well as nitrogen use efficiency (NUE) of saffron were investigated as a two-year field experiment based on a randomized complete block design arranged in split-plot with three replicates. The irrigation levels (100, 75 and 50\% of saffron water requirement) and corm planting pattern $\left(50,100,200\right.$ and $\left.300 \mathrm{corms} \mathrm{m}^{-2}\right)$ were allocated to main and sub-plots, respectively. Based on the results, crocin and picrocrocin content increased with decreasing irrigation levels. The highest $\mathrm{WUE}_{S}$ (WUE based on dry stigma yield) was obtained when $50 \%$ of saffron water requirement was supplied. However, the lowest $\mathrm{WUE}_{\mathrm{C}}$ (WUE based on daughter corms yield) and $\mathrm{NUE}_{\mathrm{C}}$ (NUE based on daughter corms yield) were obtained when $50 \%$ of saffron water requirement was applied. Irrespective of irrigation levels, $\mathrm{WUE}_{\mathcal{S}}, \mathrm{WUE}_{\mathrm{C}}$ and $\mathrm{NUE}_{\mathrm{C}}$ increased with increasing the planting density. The results demonstrated that although relatively severe water stress increases WUES and secondary metabolites in saffron stigmas, it could decrease $\mathrm{WUE}_{\mathrm{C}}$ and $\mathrm{NUE}_{\mathrm{C}}$ through affecting daughter corm growth.
\end{abstract}

Keywords: crocin, daughter corm, dry stigma yield, picrocrocin, safranal, water requirement

\section{Introduction}

Saffron (Crocus sativus L.) is a sterile geophyte plant growing in arid and semi-arid regions of the world (Sepaskhah and Kamgar-Haghighi, 2009). The medical aspects of saffron are primarily related to its secondary metabolites, such as crocin, picrocrocin and safranal, found in stigmas (Escribano $e t$ al., 1996; Tamaddonfard et al., 2014; Talaei et al., 2015). Crocin, picrocrocin and safranal are responsible for color, taste and odor of saffron, respectively (Lage and Cantrell, 2009; Srivastava et al., 2010). Hence, in addition to quantitative yield (flower or corms weight) (Koocheki et al., 2014; Khorramdel et al., 2015), qualitative yield (secondary metabolites content) is known as a crucial factor in successful saffron production (Omidi et al., 2009; Koocheki et al., 2016).

Water use efficiency (WUE) is defined as yield of marketable crop produced per unit of water used in evapotranspiration (Dong et al., 2011). It is generally believed that in the future, water availability will become increasingly scarce, particularly in arid and semi-arid regions, due to rapid urbanization, higher population growth and expanding areas of irrigation (Abbaspour and Sabetraftar, 2005; Chiew et al., 2011; de Souza and Costa da Silva, 2014). Hence, enhancing WUE is becoming increasingly important for agricultural improvement in these regions (El-Hendawy et al., 2008; Barati et al., 2015).

According to saffron's irrigation schedule, an optimal irrigation schedule consists of five to six irrigation rounds (Koocheki et al., 2014; 2016). These irrigation rounds are usually performed in mid-summer (for flowering induction), in early October (for flowering acceleration), in November (after flower picking and leaves appearance), in December (after winter weeding), in March and finally in April (supplementary irrigation for optimum daughter corm growth). However, in some arid and semi-arid regions, saffron fields are irrigated only once (in October), mainly due to water shortage, causing a significant reduction in flower and corm yields (Kafi et al., 2002; Koocheki et al., 2014). Hence, in spite of being a crop compatible with arid and semi-arid regions, with low water requirements (Alizadeh et al., 2009; Sepaskhah and KamgarHaghighi, 2009; Yarami et al., 2011), water shortage is the most important challenge in sustainable saffron production (Yarami and Sepaskhah, 2015). Therefore, it is critical to determine the amount of water by which saffron can produce maximum yield.

In addition to WUE, more attention should be paid to nitrogen use efficiency (NUE) as an important index in saffron sustainable production (Koocheki and Seyyedi, 2015). 
Nitrogen use efficiency, which is defined as the ratio of the crop yield to the total input of $\mathrm{N}$ applied, is split into acquisition and physiological efficiency (Lea and Azevedo, 2006; Salvagiotti $e t$ al., 2009). Due to being a perennial species, at least in field conditions (Kumar et al., 2009; Babaei et al., 2014), as well as having dynamic $\mathrm{N}$ allocation among leaves or underground organs (Ourry et al., 1988; Dordas, 2009), it appears that NUE in saffron is more complicated than within other annual plants (Koocheki and Seyyedi, 2015).

Optimum planting pattern based on mother corms density is one of the most factors affecting daughter corms behavior, resulting in more flower yield and of better quality (Kumar et al., 2009; Koocheki et al., 2011; 2014). Dense corm planting pattern can increase saffron production, especially during early years (Koocheki et al., 2011, 2012 and 2014). Accordingly, it was hypothesized that dense corm planting pattern would increase WUE and NUE. Therefore, this experiment was aimed to study the crocin, picrocrocin and safranal content, WUE and NUE in response to different levels of saffron water requirement (SWR) and corm planting patterns.

\section{Materials and Methods}

\section{Site description}

Two-year field experiment was carried out during 20122013 and 2013-2014 growing seasons, at experimental station of Faculty of Agriculture, Ferdowsi University of Mashhad (latitude: $36^{\circ} 15^{\prime} \mathrm{N}$; longitude: $59^{\circ} 28^{\prime} \mathrm{E}$; elevation: $985 \mathrm{~m}$ ). The study site was classified in semi-arid region located in Northeast of Iran. Monthly rainfall and average temperature during both growing seasons are given in Fig. 1. The soil was clay (US system) and alkaline in reaction $(\mathrm{pH} 8.16)$. The soil $(0-30 \mathrm{~cm})$ has bulk density $1.29 \mathrm{~g} \mathrm{~cm}^{-3}$, EC $1.13 \mathrm{dS} \mathrm{m}^{-1}$; organic carbon $0.54 \%$; available N $18 \mathrm{mg} \mathrm{kg}^{-1}$; available P mg kg${ }^{-1}$; available K $165.19 \mathrm{mg}$ $\mathrm{kg}^{-1}$; clay, sand and silt, $49.80,18.23$ and $31.79 \%$, respectively.

\section{Experimental design and field management}

The experimental design was a randomized complete block arranged in split-plot with three replicates. The irrigation levels (100, 75 and $50 \%$ of SWR equal to no water stress, mild water stress and relatively severe water stress) and corm planting pattern $\left(50,100,200\right.$ and 300 corms $\left.\mathrm{m}^{-2}\right)$ were allocated to the main and sub-plots, respectively.

SWR was calculated according to total potential evapotranspiration values in the first $(523 \mathrm{~mm})$ and second $(640$ $\mathrm{mm}$ ) year of the experiment, respectively (Yarami et al., 2011). More information about determination of SWR and irrigation schedule is given in Table 1.

Before mother corms (4-6 g) planting, composted cattle manure ( 25 ton ha ${ }^{-1}$ ) was mixed into the soil and then plots were established. The plots were $2.5 \times 1.5 \mathrm{~m}$ in size and $0.5 \mathrm{~m}$ apart. Composted cattle manure (N 1.65\%; P 0.41\%; K 0.87\%; organic carbon $28.36 \%$ ) was applied just in the first year of the experiment as the level of soil organic carbon was low (0.54\%).

Mother corms planting was done on $17^{\text {th }}$ of June 2012. Interrow distance for each density was $20 \mathrm{~cm}$. Irrigation (Table 1) was performed using polyethylene irrigation network equipped with counter. During both years of the experiment, weeds were controlled manually when required.

\section{Flower and corm measurements}

In the first year, flowers were manually picked up from mid to late of November 2012 and dried stigma yield was measured. Stigmas were dried (Fig. 2) in an oven at $30^{\circ} \mathrm{C}$ for $48 \mathrm{~h}$. At the end of first growing season, daughter corm yield was determined using a $0.5 \times 0.5 \mathrm{~m}$ quadrate per plot. The rest of the daughter corms were devoted for the second year. In the second year, flowers were manually picked up from early to late of November in 2013. Other measurements were performed same as in the first year of the experiment.

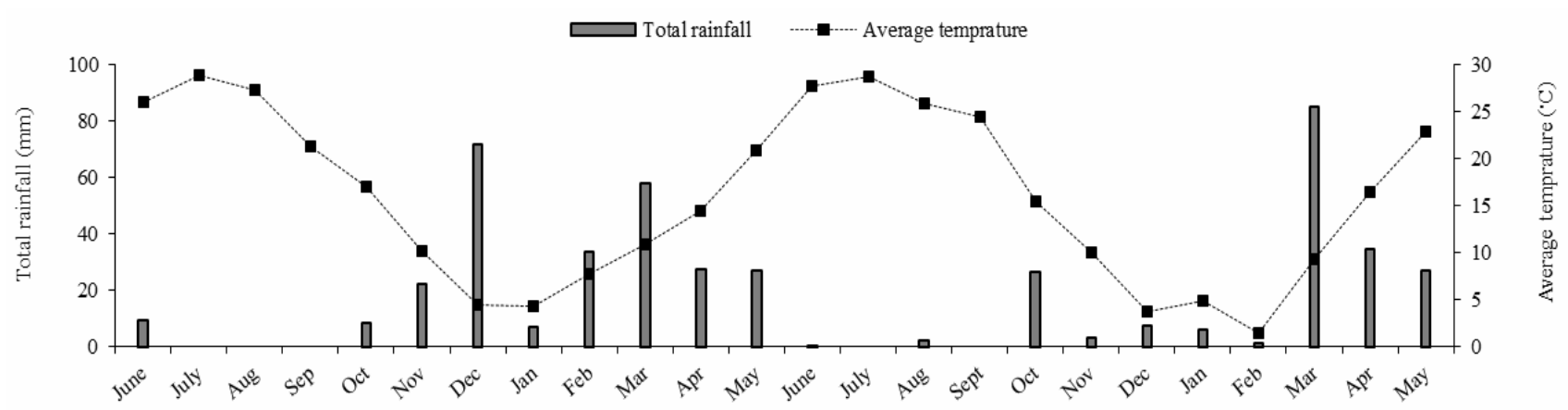

Fig. 1. Monthly rainfall and average temperature during both growing seasons (from June 2012 to May 2014)
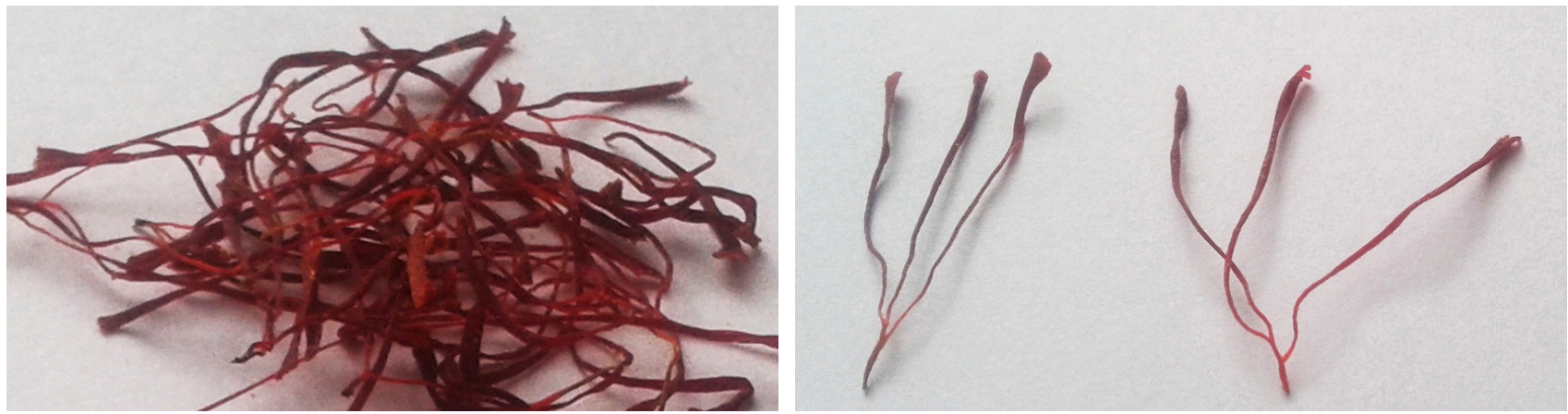

Fig. 2. Saffron stigmas after drying. Stigmas were dried in an oven at $30^{\circ} \mathrm{C}$ for $48 \mathrm{~h}$ 
Table 1. Determination of saffron water requirement (SWR) and total amount of applied water (TAAW) in the first and second years of the experiment

\begin{tabular}{|c|c|c|c|c|c|c|c|c|c|}
\hline \multirow[b]{2}{*}{ Irrigation frequency } & \multirow[b]{2}{*}{ 30-year average precipitation (mm) } & \multirow[b]{2}{*}{ Irrigation times } & \multirow[b]{2}{*}{$\begin{array}{c}\text { Growth } \\
\text { stages }\end{array}$} & \multirow[b]{2}{*}{$\begin{array}{c}\text { Crop } \\
\text { coefficien } \\
\mathrm{t}(\mathrm{Kc})\end{array}$} & \multirow{2}{*}{$\begin{array}{c}\text { Irrigation } \\
\text { rate } \\
\text { (percentage } \\
\text { of total) }\end{array}$} & \multirow[b]{2}{*}{$\begin{array}{l}\text { SWR } \\
(\mathrm{mm})\end{array}$} & \multicolumn{3}{|c|}{ TAAW (mm) to plots } \\
\hline & & & & & & & $\begin{array}{c}100 \% \text { of } \\
\text { SWR }\end{array}$ & $\begin{array}{l}75 \% \text { of } \\
\text { SWR }\end{array}$ & $\begin{array}{l}50 \% \text { of } \\
\text { SWR }\end{array}$ \\
\hline First & 4.41 (from first to second irrigation) & $8^{\text {th }}$ of August 2012 & Initial & 0.41 & 1.051 & 54.98 & 50.57 & 37.93 & 25.29 \\
\hline Second & 13.94 (from second to third irrigation) & $8^{\text {th }}$ of October 2012 & Initial & 0.41 & 10.51 & 54.98 & 41.04 & 30.78 & 20.52 \\
\hline Third & 26.05 (from third to fourth irrigation) & $16^{\text {th }}$ of November 2012 & Middle & 0.93 & 23.85 & 124.72 & 98.67 & 74.00 & 49.34 \\
\hline Fourth & 96.11 (from fourth to fifth irrigation) & $17^{\text {th }}$ of December 2012 & Middle & 0.93 & 23.85 & 124.72 & 28.61 & 21.46 & 14.31 \\
\hline Fifth & 57.55 (fifth first to sixth irrigation) & $3^{\text {th }}$ of March 2013 & Middle & 0.93 & 23.85 & 124.72 & 67.17 & 50.38 & 33.59 \\
\hline Sixth & 71.70 (from sixth irrigation to harvest) & $4^{\text {th }}$ of April 2013 & Final & 0.29 & 7.44 & 38.89 & - & - & - \\
\hline Total(first year) & 269.76 & & & & 100 & 523 & 286.06 & 214.55 & 143.03 \\
\hline First & 4.41 (from first to second irrigation) & $8^{\text {th }}$ of August 2013 & Initial & 0.45 & 10.32 & 66.06 & 61.65 & 46.24 & 30.83 \\
\hline Second & 13.94 (from second to third irrigation) & $8^{\text {th }}$ of October 2013 & Initial & 0.45 & 10.32 & 66.06 & 52.12 & 39.09 & 26.06 \\
\hline Third & 26.05 (from third to fourth irrigation) & $16^{\text {th }}$ of November 2013 & Middle & 1.05 & 24.08 & 154.13 & 128.08 & 96.06 & 64.04 \\
\hline Fourth & 96.11 (from fourth to fifth irrigation) & $20^{\text {th }}$ of December 2013 & Middle & 1.05 & 24.08 & 154.13 & 58.02 & 43.52 & 29.01 \\
\hline Fifth & 57.55 (fifth first to sixth irrigation) & $16^{\text {th }}$ of March 2014 & Middle & 1.05 & 24.08 & 154.13 & 96.58 & 72.44 & 48.29 \\
\hline Sixth & 71.70 (from sixth irrigation to harvest) & $4^{\text {th }}$ of April 2014 & Final & 0.31 & 7.11 & 45.50 & - & - & - \\
\hline Total (second year) & 269.76 & & & & 100 & 640 & 396.45 & 297.34 & 198.23 \\
\hline
\end{tabular}

SWR was calculated according to Kc coefficients at initial, middle and final growth stages in the first and second years of the experiment, respectively.

\section{Determination of crocin, picrocrocin and safranal}

In the first and second year, crocin, picrocrocin and safranal were measured based on ISO 3632 trade standard (ISO/TS 3632, 2003), using UV-vis spectrometric method. Crocin (440 $\mathrm{nm})$, picrocrocin $(257 \mathrm{~nm})$ and safranal content $(330 \mathrm{~nm})$ were expressed as direct readings of the absorbance of $1 \%$ aqueous solution of dried stigma saffron (Lage and Cantrell, 2009).

\section{Determination of WUE}

WUE (water use efficiency) was calculated as follows:

WUE $=$ Dry stigma yield $\left(\mathrm{gha}^{-1}\right) /$ Total water use $(\mathrm{mm})$ (mm)

WUE $_{C}=$ Daughter corm yield $\left(\mathrm{kg} \mathrm{ha}^{-1}\right) /$ Total water use

The total water used (TWU) was measured using the following equation (Donget al., 2011):

$\mathrm{TWU}=P+I+\Delta W$

Where: $P$ is the precipitation $(\mathrm{mm}), I$ is the irrigation $(\mathrm{mm})$, $\Delta W$ is the soil moisture change $(\mathrm{mm})$.

Due to plots design, there was no surface water runoff under the conditions of this experiment. The soil water drainage below the crop root zone $(\mathrm{mm})$ and capillary water rise to the root zone $(\mathrm{mm})$ were considered to be negligible.

\section{Determination of NAE and NUE}

Nitrogen concentration $\left(\mathrm{g} \mathrm{kg}^{-1}\right)$ in daughter corms (plus corm tunics) and aerial part was measured based on Kjeldal method (AOAC, 2000). On the basis of dry stigma and daughter corms yields, nitrogen acquisition efficiency (NAE) and nitrogen use efficiency (NUE) were calculated using the following equations (Brennan et al., 2014; Koocheki and Seyyedi, 2015):

$\operatorname{NAE}(\%)=(N t / N a) \times 100$

NUES $\left(\mathrm{gg}^{-1}\right)=S Y / \mathrm{Na}$

$\operatorname{NUE}\left(\mathrm{gg}^{-1}\right)=C Y / \mathrm{Na}$

Where: $N t$ is $\mathrm{gN}$ in the total plant $\mathrm{m}^{-2}, N a$ is $\mathrm{gN}$ applied $\mathrm{m}^{-2}$, $S Y$ is g dry stigma yield $\mathrm{m}^{-2}$, and $C Y$ is g daughter corms yield $\mathrm{m}^{-2}$.

Applied $\mathrm{N}$ was determined by the sum of following resources: 1- initial $\mathrm{N}$ content into soil before establishment of the trial (based on soil bulk density at the depth of $30 \mathrm{~cm}$ ), 2- N added by composted cattle manure, and $3-\mathrm{N}$ content in mother corms (Table 2).

\section{Statistical analysis}

Analysis of variance (ANOVA) and Duncan's multiple range tests were performed using SAS 9.3 software (SAS, 2011). Saffron traits were analyzed as split-split plot arrangement in time. The irrigation levels, corm planting density and harvesting (in the first and second year) were considered as first, second and third factors, respectively.

\section{Results and Discussion}

\section{Flower quality}

Although the effect of irrigation levels on crocin and picrocrocin content was significant, safranal content was not affected by irrigation levels (Table 3 ). In addition, the effect of planting density and harvesting year were not significant on above mentioned compounds (Table 3 ).

Interestingly, crocin and picrocrocin content increased with decreasing SWR levels. In other words, the highest crocin and picrocrocin content was observed under relatively severe water stress ( $50 \%$ of SWR) condition (Table 4).

The mechanism of saffron organic compound synthesis in response to water stress is not fully understood. As mentioned earlier, crocin and picrocrocin are the most important compounds found in saffron stigmas (Tarantilis et al., 1995; Escribano et al., 1996), so that higher amounts of these compounds leads to an increase in the quality of saffron (D'Auria et al., 2004; Srivastava et al., 2010; Koocheki et al., 2016). On the other hand, it has been reported that the quantity of essential oils and secondary metabolites in plants would increase in response to drought stress (Singh-Sangwan $e t$ al., 1994; Reddy et al., 2004). In addition, an increase in

Table 2. $\mathrm{N}$ content $\left(\mathrm{g} \mathrm{m}^{-2}\right)$ in saffron mother corms $(4-6 \mathrm{~g})$

\begin{tabular}{cccc}
\hline $\begin{array}{c}\text { Average weight } \\
\text { of mother } \\
\text { corm }(\mathrm{g})\end{array}$ & $\begin{array}{c}\text { N concentration in } \\
\text { mother corms } \\
\left(\mathrm{g} \mathrm{kg}^{-1}\right)\end{array}$ & $\begin{array}{c}\text { Planting } \\
\text { density } \\
\left(\text { corm m}^{-2}\right)\end{array}$ & $\begin{array}{c}\text { N content in } \\
\text { mother corms } \\
\left(\mathrm{g} \mathrm{m}^{-2}\right)\end{array}$ \\
\hline 5 & 12.70 & 50 & 3.18 \\
5 & 12.70 & 100 & 6.35 \\
5 & 12.70 & 200 & 12.70 \\
5 & 12.70 & 300 & 19.05 \\
\hline
\end{tabular}


Table 3. Analysis of variance for the studied traits of saffron

\begin{tabular}{|c|c|c|c|c|c|c|c|c|c|}
\hline S.O.V & $\mathrm{df}$ & Crocin & Picrocrocin & Safranal & WUEs & WUEC & NAE & NUEs & $\mathrm{NUE}_{\mathrm{C}}$ \\
\hline Block & 2 & $69.67 \mathrm{~ns}$ & $7.39 \mathrm{~ns}$ & $0.49 \mathrm{~ns}$ & $3.16^{*}$ & $85.83^{* *}$ & $64.54^{* *}$ & $0.0000014^{*}$ & $38.88^{* *}$ \\
\hline Irrigation $(I)$ & 2 & $13789.51^{\text {** }}$ & $1418.15^{* *}$ & $4.61 \mathrm{~ns}$ & $44.55^{* *}$ & $2213.76^{* *}$ & $4114.38^{* *}$ & $0.0000030^{* *}$ & $2426.94^{* *}$ \\
\hline Error I & 4 & 66.48 & 16.50 & 6.36 & 0.615 & 31.01 & 30.95 & 0.0000002 & 15.45 \\
\hline Planting density $(D)$ & 3 & $61.41 \mathrm{~ns}$ & $7.58 \mathrm{~ns}$ & $20.79 \mathrm{~ns}$ & $159.76^{* *}$ & $4024.60^{* *}$ & $942.64^{* *}$ & $0.0000518^{* *}$ & $1135.66^{* *}$ \\
\hline$I \times D$ & 6 & $95.45 \mathrm{~ns}$ & $29.63 \mathrm{~ns}$ & $4.38 \mathrm{~ns}$ & $3.85^{* *}$ & $191.32^{* *}$ & $103.84^{* *}$ & $0.0000001^{*}$ & $95.16^{* *}$ \\
\hline Error II & 18 & 85.72 & 9.30 & 6.75 & 0.92 & 21.26 & 12.71 & 0.0000004 & 11.68 \\
\hline Harvesting or year $(H)$ & 1 & $120.07 \mathrm{~ns}$ & $5.01 \mathrm{~ns}$ & $6.70 \mathrm{~ns}$ & $0.18 \mathrm{~ns}$ & $227.66^{* *}$ & $2725.56^{* *}$ & $0.0000103^{* *}$ & $725.36^{* *}$ \\
\hline$I \times H$ & 2 & $14.71 \mathrm{~ns}$ & $0.02 \mathrm{~ns}$ & $15.33 \mathrm{~ns}$ & $5.93^{* *}$ & $183.69^{* *}$ & $165.40^{* *}$ & $0.0000014^{*}$ & $85.40^{* *}$ \\
\hline$D \times H$ & 3 & $108.72 \mathrm{~ns}$ & $8.85 \mathrm{~ns}$ & $6.83 \mathrm{~ns}$ & $16.88^{* *}$ & $97.77^{* *}$ & $29.25^{*}$ & $0.0000056^{* *}$ & $36.03^{* *}$ \\
\hline$I \times D \times H$ & 6 & $179.45 \mathrm{~ns}$ & $10.42 \mathrm{~ns}$ & $7.26 \mathrm{~ns}$ & $1.17 \mathrm{~ns}$ & $1.93 \mathrm{~ns}$ & $4.39 \mathrm{~ns}$ & $0.0000002 \mathrm{~ns}$ & $2.86 \mathrm{~ns}$ \\
\hline Error III & 24 & 104.52 & 27.20 & 11.02 & 0.86 & 4.79 & 7.38 & 0.0000003 & 2.26 \\
\hline CV (\%) & - & 4.46 & 6.55 & 8.97 & 17.27 & 16.50 & 6.70 & 14.24 & 16.07 \\
\hline
\end{tabular}

The asterisks ${ }^{*},{ }^{* *}$, or ns indicate statistical differences at $\mathrm{p} \leq 0.05, \mathrm{p} \leq 0.01$, or non-significant, respectively. WUES: water use efficiency (WUE) based on dry stigma yield; WUEC: WUE based on daughter corms yield; NAE: nitrogen acquisition efficiency; NUES: nitrogen use efficiency (NUE) based on dry stigma yield; NUEC: NUE based on daughter corms yield.

Table 4. Effects of irrigation, planting density and harvesting (year) on studied traits of saffron

\begin{tabular}{|c|c|c|c|c|c|c|c|c|}
\hline \multirow[b]{2}{*}{ Experimental treatments } & \multicolumn{3}{|c|}{ UV-visible } & \multirow{2}{*}{$\begin{array}{l}\text { WUEs } \\
\left(\mathrm{g} \mathrm{ha}^{-1}\right. \\
\left.\mathrm{mm}^{-1}\right)\end{array}$} & \multirow{2}{*}{$\begin{array}{c}\text { WUEC } \\
\left(\mathrm{kg} \mathrm{ha}^{-1}\right. \\
\left.\mathrm{mm}^{-1}\right)\end{array}$} & \multirow[b]{2}{*}{$\begin{array}{l}\text { NAE } \\
(\%)\end{array}$} & \multirow[b]{2}{*}{$\begin{array}{l}\text { NUEs } \\
\left(\mathrm{g} \mathrm{g}^{-1}\right)\end{array}$} & \multirow[b]{2}{*}{$\begin{array}{l}\text { NUE } \\
\left(\mathrm{g} \mathrm{g}^{-1}\right)\end{array}$} \\
\hline & $\begin{array}{l}\text { Crocin } \\
\left(E_{440}^{176}\right)\end{array}$ & $\begin{array}{c}\text { Picrocrocin } \\
\left(E_{257}^{1 \%}\right)\end{array}$ & $\begin{array}{l}\text { Safranal } \\
\left(E_{300}^{276}\right)\end{array}$ & & & & & \\
\hline \multicolumn{9}{|c|}{ Irrigation (percentage of water requirement) } \\
\hline 50 & $251.05 \mathrm{a}$ & $87.67 \mathrm{a}$ & $37.29 a$ & $6.66 \mathrm{a}$ & $26.66 \mathrm{c}$ & $25.48 c$ & $0.0032 \mathrm{~b}$ & $13.19 \mathrm{c}$ \\
\hline 75 & $233.68 \mathrm{~b}$ & $78.71 \mathrm{~b}$ & $37.24 \mathrm{a}$ & $5.50 \mathrm{~b}$ & $44.63 \mathrm{a}$ & $49.12 \mathrm{a}$ & $0.0038 \mathrm{a}$ & $31.43 \mathrm{a}$ \\
\hline 100 & $203.67 c$ & $72.37 c$ & $36.51 \mathrm{a}$ & $3.94 \mathrm{c}$ & $29.77 b$ & $47.05 b$ & $0.0039 a$ & $29.64 b$ \\
\hline \multicolumn{9}{|l|}{ Planting density $\left(\right.$ corm $\left.\mathrm{m}^{-2}\right)$} \\
\hline 50 & $232.00 \mathrm{a}$ & $79.08 \mathrm{a}$ & $37.80 \mathrm{a}$ & $2.00 \mathrm{~d}$ & $19.33 \mathrm{~d}$ & $32.50 \mathrm{~d}$ & $0.0016 \mathrm{c}$ & $16.64 \mathrm{~d}$ \\
\hline 100 & $229.49 a$ & $80.22 \mathrm{a}$ & $37.76 \mathrm{a}$ & $3.75 \mathrm{c}$ & $24.04 \mathrm{c}$ & $36.67 \mathrm{c}$ & $0.0029 \mathrm{~b}$ & $19.91 \mathrm{c}$ \\
\hline 200 & $228.72 \mathrm{a}$ & $80.06 \mathrm{a}$ & $35.50 \mathrm{a}$ & $7.44 b$ & $39.23 \mathrm{~b}$ & $44.80 \mathrm{~b}$ & $0.0051 \mathrm{a}$ & $28.38 \mathrm{~b}$ \\
\hline 300 & $227.66 \mathrm{a}$ & $78.97 \mathrm{a}$ & $36.99 \mathrm{a}$ & $8.26 \mathrm{a}$ & $52.14 \mathrm{a}$ & $48.24 \mathrm{a}$ & $0.0050 \mathrm{a}$ & $34.07 \mathrm{a}$ \\
\hline \multicolumn{9}{|l|}{ Harvesting (year) } \\
\hline First harvest (first year) & $230.76 \mathrm{a}$ & $79.85 \mathrm{a}$ & $37.32 \mathrm{a}$ & $5.31 \mathrm{a}$ & $31.91 \mathrm{~b}$ & $34.40 \mathrm{~b}$ & $0.0033 \mathrm{~b}$ & $21.58 \mathrm{~b}$ \\
\hline Second harvest (second year) & $228.18 \mathrm{a}$ & $79.32 \mathrm{a}$ & $36.71 \mathrm{a}$ & $5.41 \mathrm{a}$ & $35.46 \mathrm{a}$ & $46.70 \mathrm{a}$ & $0.0040 \mathrm{a}$ & $27.93 \mathrm{a}$ \\
\hline
\end{tabular}

Values followed by the same letter were not significantly different at $\mathrm{p} \leq 0.05$ (DMRT). WUES: water use efficiency (WUE) based on dry stigma yield; WUEC: WUE based on daughter corms yield; NAE: nitrogen acquisition efficiency; NUES: nitrogen use efficiency (NUE) based on dry stigma yield; NUEC: NUE based on daughter corms yield.

protein content, peroxidase and superoxide dismutase activity, in response to drought stress, has been documented by Maleki et al. (2011). Consequently, it seems that increase in crocin and picrocrocin synthesis in response to drought stress is a compatibility mechanism in saffron.

\section{Interaction between irrigation and plantingpattern}

Irrespective of irrigation levels, WUEs, WUEc, NAE, $\mathrm{NUE}_{S}$ and $\mathrm{NUE}_{\mathrm{C}}$ increased with increasing planting density (Table 5). For instance, in full irrigated plants (100\% of SWR), an increase in planting density from 50 to 300 corms $\mathrm{m}^{-2}$ increased WUEs and NUE by 4 and 2 times, respectively.

As mentioned above, dense corm planting pattern not only improved flower yield during early years, but also promoted sustainable production of saffron (Koocheki et al., 2011; 2016). According to the literature, an increase in planting density can be a good approach to deal with water loss in arid regions (Stroosnijder et al., 2012). Hence, it seemed that dense planting pattern can increase NUE in saffron through more $\mathrm{N}$ uptake and help to reduce water loss.

In each level of planting density, the highest WUEs was obtained when $50 \%$ of SWR was applied (Table 5). This might be due to flowering adaptation mechanisms to drought stress (Sepaskhah, 2009). In other words, drought stress is an incentive factor for flowering which in turns resulted in maximum WUEs.

Regardless of the planting density, the lowest and highest $\mathrm{WUE}_{\mathrm{C}}$ were obtained when saffron plants were irrigated with 50 and $75 \%$ of SWR, respectively. Under same conditions, in terms of planting density, the lowest NAE, NUE and $\mathrm{NUE}_{\mathrm{C}}$ were recorded when $50 \%$ of SWR was applied (Table 5). For example, when 50 corms $\mathrm{m}^{-2}$ were cultivated, a reduction in irrigation water from 100 to $50 \%$ of SWR decreased NAE by $41.98 \%$.

It appeared that mild water stress (supplying $75 \%$ of SWR), stimulated daughter corms growth through increasing root growth and better nutrients uptake, especially $\mathrm{N}$. In other words, a slight reduction in water availability would increase corm yield per unit of available water. Nevertheless, considering the sensitivity of saffron to water shortage (Sepaskhah and Yarami, 2009; RenauMorata et al., 2012; Yarami and Sepaskhah, 2015), sever stress would negatively affect daughter corm growth, NAE, NUEs and NUEc. In this regard, Renau-Morata $e t$ al. (2012) observed a decrease in the photosynthetic rate of saffron under water stress. Motalebifard et al. (2013) showed that water deficit stress caused a significant reduction in tuber numbers, yield and WUE of potato (Solanum tuberosum L. cv. 'Agria'). 
Interaction between irrigation and harvesting (year)

The results revealed that when 75 and $100 \%$ of SWR was applied, more WUEs, WUEc, NAE, NUEs and NUEC were registered in the second year rather than the first year of the experiment (Table 6). For instance, in full irrigated plots, NAE in the second year increased by $32.6 \%$ compared with the first year (Table 6).

Saffron is a plant that propagates by mean of corms, which are renewing each year. Above and underground organs grow more from year to year (Kumar et al., 2009; Koocheki et al., 2014), thus more nutrients are absorbed from the soil over the time (Koocheki et al., 2016). Moreover, higher growth of aerial part and roots cause lower water loss. According to the previous figures, developed above ground organs stimulate root growth and in turns improve plant capability to uptake water and nutrients. Therefore increasing plant density would increase WUE in crops (Sani et al., 2008; Stroosnijder et al., 2012).

Interaction between planting density and harvesting (year)

From the results obtained, when 50, 100 and 200 corms $\mathrm{m}^{-2}$ were cultivated, more $\mathrm{WUE}_{S}$, WUE, NAE, NUE and NUEs were recorded in the second year compared with the first year (Table 7). However, when 300 corms $\mathrm{m}^{-2}$ were cultivated, more WUE and $\mathrm{WUE}_{\mathrm{C}}$ were recorded in the first year compared with the second year (Table 7). This might be due to more small corms, formed at the end of the first year, in 300 corms $\mathrm{m}^{-2}$ treatment. In this regard, Koocheki et al. (2012) found that an increase in planting density up to 400 corm $\mathrm{m}^{-2}$ increased the ratio of small daughter corms to total daughter corm. It has been reported that there is a positive relationship between corm size and flowering ability (Gresta et al., 2008; Douglas et al., 2014). Therefore, small corms formation in the first year and less flower production in the second year may be considered as the main reasons for reduction of WUEs and $\mathrm{WUE}_{C}$ in saffron.

\section{Correlation between water consumption and $N$ uptake}

There was a positive and significant correlation between WUE $_{C}$ and NAE (Fig. 3A), WUE and $\mathrm{NUE}_{S}$ (Fig. 3B) and WUE $_{C}$ and $\mathrm{NUE}_{\mathrm{C}}$ (Fig. 3C). These results suggested that effective approaches for increasing $\mathrm{WUE}_{\mathrm{C}}$ can be practiced through stimulating daughter corms growth and more $\mathrm{N}$ uptake from the soil, which improve flower yield per each unit of absorbed N. From the other point of view, considering the key role of $\mathrm{N}$ in stimulating vegetative growth, daughter corms formation and flower production (Chaji et al., 2013), it seems that higher NUE causes less soil evaporation and more saffron yield per unit of consumed water.

\begin{tabular}{|c|c|c|c|c|c|c|c|c|c|}
\hline \multirow{2}{*}{$\begin{array}{c}\text { Irrigation } \\
\text { (percentage of } \\
\text { water } \\
\text { requirement) }\end{array}$} & \multirow{2}{*}{$\begin{array}{c}\text { Planting } \\
\text { density } \\
\left(\text { corm m }^{-2}\right)\end{array}$} & \multicolumn{3}{|c|}{ UV-visible } & \multirow[b]{2}{*}{$\begin{array}{c}\text { WUEs } \\
\left(\mathrm{gha}^{-1} \mathrm{~mm}^{-1}\right)\end{array}$} & \multirow[b]{2}{*}{$\begin{array}{c}\text { WUEC } \\
\left(\mathrm{kgha}^{-1} \mathrm{~mm}^{-1}\right)\end{array}$} & \multirow[b]{2}{*}{ NAE(\%) } & \multirow[b]{2}{*}{$\mathrm{NUE}_{S}\left(\mathrm{gg}^{-1}\right)$} & \multirow[b]{2}{*}{$\operatorname{NUE}_{\mathrm{C}}\left(\mathrm{gg}^{-1}\right)$} \\
\hline & & $\begin{array}{l}\text { Crocin } \\
\left(E_{440}^{1 \%}\right)\end{array}$ & $\begin{array}{l}\text { Picrocrocin } \\
\left(E_{257}^{196}\right)\end{array}$ & $\begin{array}{l}\text { Safranal } \\
\left(E_{770}^{1 \% 6}\right)\end{array}$ & & & & & \\
\hline \multirow{4}{*}{50} & 50 & $252.27(4.86)$ & $88.23(4.31)$ & $37.82(3.20)$ & $2.38(0.60)$ hi & $15.99(2.13) \mathrm{h}$ & $22.03(2.81) \mathrm{g}$ & $0.0014(0.0005) \mathrm{d}$ & $9.24(1.45) \mathrm{f}$ \\
\hline & 100 & $246.08(4.20)$ & $89.38(6.53)$ & $37.37(2.56)$ & $4.69(0.79)$ ef & 18.61 (2.93) gh & $22.48(6.12) \mathrm{g}$ & $0.0026(0.0005) \mathrm{bcd}$ & $10.26(2.50)$ ef \\
\hline & 200 & $254.04(5.76)$ & $88.27(6.55)$ & $35.66(4.58)$ & $9.20(1.59) \mathrm{ab}$ & 28.83 (1.12) def & $26.93(3.91) \mathrm{f}$ & $0.0045(0.0010) \mathrm{a}$ & $14.15(1.70) \mathrm{e}$ \\
\hline & 300 & $251.82(9.81)$ & $84.81(4.25)$ & $38.33(3.09)$ & $10.35(3.19) \mathrm{a}$ & $43.21(5.92) \mathrm{c}$ & $30.48(3.77) \mathrm{f}$ & $0.0045(0.0011) \mathrm{a}$ & $19.09(2.14) \mathrm{d}$ \\
\hline \multirow{4}{*}{75} & 50 & $239.02(5.11)$ & $79.50(1.96)$ & $37.94(3.86)$ & $2.18(0.92)$ hi & $24.42(5.69)$ efg & $37.49(9.71) \mathrm{e}$ & 0.0018 (0.0008) bcd & $20.18(5.45) d$ \\
\hline & 100 & $237.48(4.02)$ & $76.98(0.86)$ & $37.74(3.09)$ & $3.72(1.18) \mathrm{fg}$ & $29.80(8.90) \mathrm{de}$ & $42.25(11.71) \mathrm{cd}$ & $0.0029(0.0010) b c$ & $23.30(7.84) \mathrm{cd}$ \\
\hline & 200 & $229.63(3.63)$ & $77.99(2.86)$ & $35.87(1.63)$ & $7.67(1.84) \mathrm{c}$ & $57.01(9.74) b$ & $58.77(9.40) \mathrm{a}$ & $0.0054(0.0015) \mathrm{a}$ & $39.74(7.82) \mathrm{a}$ \\
\hline & 300 & $228.58(5.98)$ & $80.37(2.24)$ & $37.42(2.42)$ & $8.41(1.19) \mathrm{bc}$ & $67.29(5.12) \mathrm{a}$ & $57.96(9.40) \mathrm{a}$ & $0.0053(0.0006) \mathrm{a}$ & $42.49(4.29) \mathrm{a}$ \\
\hline \multirow{4}{*}{100} & 50 & $204.71(15.80)$ & $69.51(5.19)$ & $37.65(2.72)$ & $1.46(0.39) \mathrm{i}$ & $17.58(2.05) \mathrm{h}$ & $37.97(9.02) \mathrm{de}$ & $0.0017(0.0006) \mathrm{cd}$ & $20.51(4.27) \mathrm{d}$ \\
\hline & 100 & $204.90(18.58)$ & $74.31(1.96)$ & $38.18(3.30)$ & $2.82(0.76) \mathrm{gh}$ & $23.70(4.06) \mathrm{fg}$ & $45.27(10.17) b c$ & $0.0031(0.0011) \mathrm{b}$ & $26.17(6.71) c$ \\
\hline & 200 & $202.48(16.30)$ & $73.93(1.69)$ & $34.98(0.64)$ & $5.46(0.64) \mathrm{de}$ & $31.85(3.62) \mathrm{d}$ & $48.70(6.72) b$ & $0.0054(0.0009) \mathrm{a}$ & $31.25(4.87) \mathrm{b}$ \\
\hline & 300 & $202.58(8.93)$ & $71.75(5.03)$ & $35.22(1.93)$ & $6.03(1.11) \mathrm{d}$ & $45.93(4.76) \mathrm{c}$ & $56.28(7.27) \mathrm{a}$ & $0.0053(0.0005) \mathrm{a}$ & $40.63(3.40) \mathrm{a}$ \\
\hline
\end{tabular}

Values followed by the same letter were not significantly different at $p \leq 0.05$ (DMRT). Values in the parenthesis indicate standard deviation ( \pm ) of means. WUEs: water use efficiency (WUE) based on dry stigma yield; WUEc: WUE based on daughter corms yield; NAE: nitrogen acquisition efficiency; NUEs: nitrogen use efficiency (NUE) based on dry stigma yield; NUEc: NUE based on daughter corms yield.

Table 6. Interaction effects of irrigation and harvesting (year) on studied traits of saffron

\begin{tabular}{|c|c|c|c|c|c|c|c|c|c|}
\hline \multirow{2}{*}{$\begin{array}{c}\text { Irrigation } \\
\text { (percentage of } \\
\text { water } \\
\text { requirement) }\end{array}$} & \multirow[b]{2}{*}{$\begin{array}{l}\text { Harvesting } \\
\text { (year) }\end{array}$} & \multicolumn{3}{|l|}{ UV-visible } & \multirow[b]{2}{*}{$\begin{array}{c}\text { WUE }_{S} \\
\left(\mathrm{gha}^{-1} \mathrm{~mm}^{-1}\right)\end{array}$} & \multirow[b]{2}{*}{$\begin{array}{c}\text { WUEC } \\
\left(\mathrm{kgha}^{-1} \mathrm{~mm}^{-1}\right)\end{array}$} & \multirow[b]{2}{*}{ NAE $(\%)$} & \multirow[b]{2}{*}{$\operatorname{NUEs}\left(\mathrm{gg}^{-1}\right)$} & \multirow[b]{2}{*}{$\operatorname{NUE} c\left(g^{-1}\right)$} \\
\hline & & $\begin{array}{l}\text { Crocin } \\
\left(\boldsymbol{E}_{450}^{176}\right)\end{array}$ & $\begin{array}{l}\text { Picrocrocin } \\
\left(E_{257}^{166}\right)\end{array}$ & $\begin{array}{l}\text { Safranal } \\
\left(E_{330}^{1 \%}\right)\end{array}$ & & & & & \\
\hline \multirow{2}{*}{50} & $\begin{array}{l}\text { First harvest } \\
\text { (first year) }\end{array}$ & $252.80(7.10)$ & $87.97(5.55)$ & $37.04(4.16)$ & $7.09(4.43) \mathrm{a}$ & $26.85(13.14) d$ & $22.14(4.40) \mathrm{e}$ & $0.0031(0.0017) \mathrm{b}$ & $12.03(4.62) \mathrm{e}$ \\
\hline & $\begin{array}{l}\text { Second harvest } \\
\text { (second year) }\end{array}$ & $249.30(6.31)$ & $87.38(5.57)$ & $37.54(2.51)$ & $6.22(3.05) b$ & $26.47(9.95) \mathrm{d}$ & $28.81(4.07) \mathrm{d}$ & $0.0034(0.0015) b$ & $14.34(3.96) \mathrm{d}$ \\
\hline \multirow[t]{2}{*}{75} & First harvest & $234.07(6.18)$ & $78.94(2.77)$ & $38.46(3.27)$ & $4.94(3.25) \mathrm{c}$ & $39.69(20.93) b$ & $\begin{array}{c}40.59(11.14) \\
c\end{array}$ & $0.0033(0.0019) \mathrm{b}$ & $26.53(11.69) \mathrm{c}$ \\
\hline & Second harvest & $233.29(7.03)$ & $78.47(2.01)$ & $36.02(1.57)$ & $6.05(2.63) b$ & $49.57(17.92) \mathrm{a}$ & $57.65(9.78) \mathrm{a}$ & $0.0044(0.0017) \mathrm{a}$ & $36.32(9.91) \mathrm{a}$ \\
\hline \multirow{2}{*}{100} & First harvest & $205.41(12.65)$ & $72.64(4.90)$ & $36.45(3.36)$ & $3.91(2.47) \mathrm{d}$ & $29.18(13.56) \mathrm{c}$ & $40.46(8.61) c$ & $0.0034(0.0019) \mathrm{b}$ & $26.17(9.48) \mathrm{c}$ \\
\hline & Second harvest & $201.93(16.23)$ & $72.11(3.27)$ & $36.57(1.82)$ & $3.97(1.62) \mathrm{d}$ & $30.35(9.34) c$ & $53.65(7.36) \mathrm{b}$ & $0.0043(0.0015) \mathrm{a}$ & $33.11(6.94) b$ \\
\hline
\end{tabular}

Values followed by the same letter were not significantly different at $p \leq 0.05$ (DMRT). Values in the parenthesis indicate standard deviation $( \pm)$ of means. WUEs: water use efficiency (WUE) based on dry stigma yield: WUEc: WUE based on daughter corms yield; NAE: nitrogen acquisition efficiency; NUEs: nitrogen use efficiency (NUE) based on dry stigma yield; NUEc: NUE based on daughter corms yield. 
Table 7. Interaction effects of planting density and harvesting (year) on studied traits of saffron

\begin{tabular}{|c|c|c|c|c|c|c|c|c|c|}
\hline \multirow[b]{2}{*}{$\begin{array}{c}\text { Planting } \\
\text { density } \\
\left(\text { corm m }^{2}\right)\end{array}$} & \multirow[b]{2}{*}{$\begin{array}{l}\text { Harvesting } \\
\text { (year) }\end{array}$} & \multicolumn{3}{|c|}{ UV-visible } & \multirow[b]{2}{*}{$\begin{array}{c}\text { WUEs } \\
\left(\mathrm{gha}^{-1} \mathrm{~mm}^{-1}\right)\end{array}$} & \multirow[b]{2}{*}{$\begin{array}{c}\text { WUEC } \\
\left(\mathrm{kgha}^{-1} \mathrm{~mm}^{-1}\right)\end{array}$} & \multirow[b]{2}{*}{ NAE (\%) } & \multirow[b]{2}{*}{$\mathrm{NUE}_{\mathrm{S}}\left(\mathrm{gg}^{-1}\right)$} & \multirow[b]{2}{*}{$\operatorname{NUE}\left(g^{-1}\right)$} \\
\hline & & $\begin{array}{l}\text { Crocin } \\
\left(E_{440}^{174}\right)\end{array}$ & $\begin{array}{c}\text { Picrocrocin } \\
\left(E_{257}^{176}\right)\end{array}$ & $\begin{array}{l}\text { Safranal } \\
\left(E_{330}^{17 / 6}\right)\end{array}$ & & & & & \\
\hline \multirow[b]{2}{*}{50} & $\begin{array}{l}\text { First harvest } \\
\text { (first year) }\end{array}$ & $233.55(25.52)$ & $79.91(9.56)$ & $38.99(3.47)$ & $1.50(0.49) \mathrm{f}$ & $17.21(2.59) \mathrm{g}$ & $26.09(5.04) \mathrm{e}$ & $0.0011(0.0002) \mathrm{f}$ & $13.55(4.05) \mathrm{e}$ \\
\hline & $\begin{array}{c}\text { Second } \\
\text { harvest } \\
\text { (second year) }\end{array}$ & $230.44(20.83)$ & $78.25(8.34)$ & $36.61(2.28)$ & $2.51(0.63) \mathrm{e}$ & $21.45(6.25) f$ & $38.90(10.98) \mathrm{c}$ & $0.0022(0.0004) \mathrm{e}$ & $19.73(7.43) \mathrm{d}$ \\
\hline \multirow[b]{2}{*}{100} & First harvest & $234.12(12.98)$ & $79.74(6.93)$ & $37.89(3.50)$ & $3.30(1.18) \mathrm{de}$ & $19.62(2.90) \mathrm{f}$ & $28.92(9.44) \mathrm{d}$ & $0.0023(0.0003) \mathrm{e}$ & $14.94(5.59) \mathrm{e}$ \\
\hline & $\begin{array}{l}\text { Second } \\
\text { harvest }\end{array}$ & $224.86(26.98)$ & $80.70(8.83)$ & $37.64(2.20)$ & $4.19(1.04) \mathrm{d}$ & $28.46(7.74) \mathrm{e}$ & $44.42(13.40) b$ & $0.0035(0.0009) \mathrm{d}$ & $24.87(9.57) \mathrm{c}$ \\
\hline \multirow[b]{2}{*}{200} & Firstharvest & $228.65(23.38)$ & $79.87(7.44)$ & $35.26(3.42)$ & $6.80(2.08) \mathrm{c}$ & $37.41(12.14) \mathrm{d}$ & $39.04(12.10) \mathrm{c}$ & $0.0043(0.0008) \mathrm{cd}$ & $25.24(10.44) \mathrm{c}$ \\
\hline & $\begin{array}{l}\text { Second } \\
\text { harvest }\end{array}$ & $228.79(25.42)$ & $80.25(7.76)$ & $35.74(1.88)$ & $8.09(2.00) b$ & $41.06(16.51) \mathrm{c}$ & $50.56(16.41) \mathrm{a}$ & $0.0059(0.0008) \mathrm{a}$ & $31.52(13.36) b$ \\
\hline \multirow[b]{2}{*}{300} & First harvest & $226.71(25.30)$ & $79.87(8.31)$ & $37.14(3.60)$ & $9.66(2.67) \mathrm{a}$ & $53.40(10.18) a$ & $43.54(12.11) b$ & $0.0055(0.0005) \mathrm{ab}$ & $32.57(10.79) \mathrm{b}$ \\
\hline & $\begin{array}{l}\text { Second } \\
\text { harvest }\end{array}$ & $228.61(20.00)$ & $78.08(5.05)$ & $36.84(1.66)$ & $6.86(1.88) \mathrm{c}$ & $50.89(14.36) \mathrm{b}$ & $52.94(16.02) \mathrm{a}$ & $0.0046(0.0009) \mathrm{bc}$ & $35.58(12.40) \mathrm{a}$ \\
\hline
\end{tabular}

Values followed by the same letter were not significantly different at $\mathrm{p} \leq 0.05$ (DMRT). Values in the parenthesis indicate standard deviation $( \pm$ ) of means. WUES: water use efficiency (WUE) based on dry stigma yield; WUEC: WUE based on daughter corms yield; NAE: nitrogen acquisition efficiency; NUES: nitrogen use efficiency (NUE) based on dry stigma yield; NUEC: NUE based on daughter corms yield.

$\mathbf{A}$

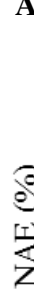

2)

B
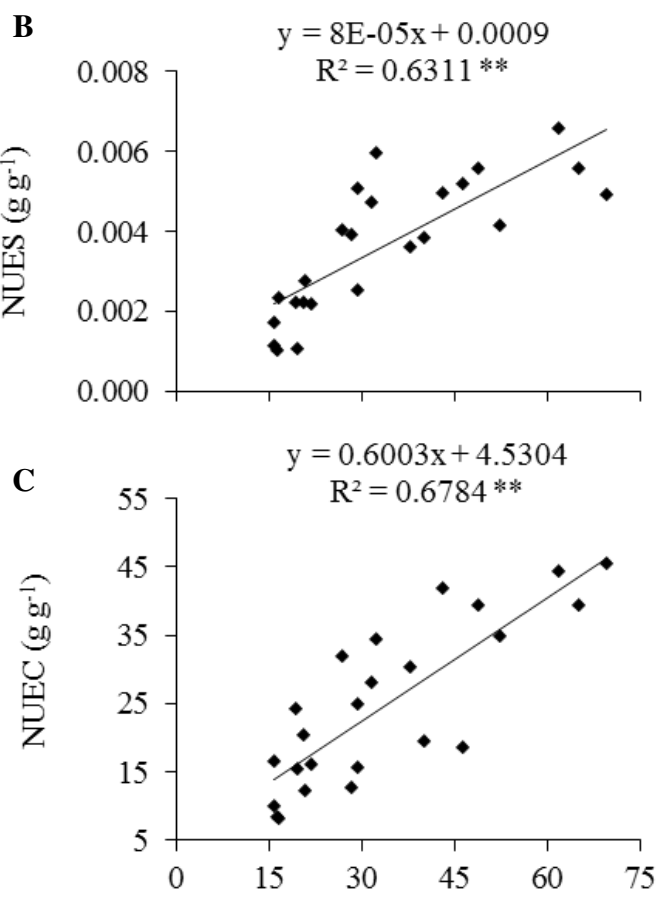

WUEC $\left(\mathrm{kg} \mathrm{ha}^{-1} \mathrm{~mm}^{-1}\right)$

Fig. 3. Relationship between $\mathrm{WUE}_{\mathrm{C}}$ and $\mathrm{NAE}(\mathrm{A}), \mathrm{WUE}_{\mathrm{C}}$ and $\mathrm{NUE}_{S},(\mathrm{~B})$ and $\mathrm{WUE}$ and $\mathrm{NUE}_{\mathrm{C}}(\mathrm{C})$ WUE: water use efficiency based on daughter corms yield; NAE: nitrogen acquisition efficiency; NUEs: nitrogen use efficiency (NUE) based on dry stigma yield; NUE : NUE based on daughter corms yield.

\section{Conclusions}

Generally, the results demonstrated that dense planting pattern can be an effective approach for increasing WUE and NUE in saffron production. Furthermore, the results indicated that although relatively severe water stress increases WUEs and secondary metabolites in saffron stigmas, it could decrease WUE, NAE, NUEs and $\mathrm{NUE}_{\mathrm{C}}$ through affecting daughter corm growth. Considering the positive relationship found between $\mathrm{WUE}_{\mathrm{C}}$ and $\mathrm{NAE}, \mathrm{WUE}_{\mathrm{C}}$ and $\mathrm{NUE}_{S}$, as well as between WUEC $_{C}$ and $\mathrm{NUE}_{\mathrm{C}}$, it can be stated that the crucial factors affecting daughter corms growth can lead to more efficient use of water and nitrogen in saffron crop.

\section{Acknowledgements}

The authors acknowledge the financial support of this project (grant number 1/23264) by Vice President for Research and Technology, Ferdowsi University of Mashhad, Iran.

\section{References}

Abbaspour M, Sabetraftar A (2005). Review of cycles and indices of drought and their effect on water resources, ecological, biological, agricultural, social and economical issues in Iran. International Journal of Environmental Studies 62:709-724.

Alizadeh A, Sayari N, Ahmadian J, Mohamadian A (2009). Study for zoning the most appropriate time of irrigation of saffron (Crocus Sativus) in Khorasan Razavi, north and southern provinces. Journal of Water and Soil 23:109-118.

Babaei S, Talebi M, Bahar M, Zeinali H (2014). Analysis of genetic diversity among saffron (Crocus sativus) accessions from different regions of Iran as revealed by SRAP markers. Scientia Horticulturae 171:27-31.

Barati V, Ghadiri H, Zand-Parsa S, Karimian N (2015). Nitrogen and water use efficiencies and yield response of barley cultivars under 
340

different irrigation and nitrogen regimes in a semi-arid Mediterranean climate. Archives of Agronomy and Soil Science 61:15-32.

Brennan J, Hackett R, McCabe T, Grant J, Fortune RA, Forristal PD (2014). The effect of tillage system and residue management on grain yield and nitrogen use efficiency in winter wheat in a cool Atlantic climate 2015. European Journal of Agronomy 54:61- 69.

Chaji N, Khorassani R, Astaraei AR, Lakzian A (2013). Effect of phosphorous and nitrogen on vegetative growth and production of daughter corms of saffron. Journal of Saffron Research 1:1-12.

Chiew FHS, Young WJ, Cai W, TengJ (2011). Current drought and future hydroclimate projections in southeast Australia and implications for water resources management. Stochastic Environmental Research and Risk Assessment 25:601-612.

D’Auria M, Mauriello G, Rana GL (2004). Volatile organic compounds from saffron. Flavour and Fragrance Journal 19:1723.

de Souza EV, Costa da Silva MA (2014). Management system for improving the efficiency of use water systems water supply. Procedia Engineering 70:458-466.

Dong B, Shi L, Shi C, Qiao Y, Liu M, Zhang Z (2011). Grain yield and water use efficiency of two types of winter wheat cultivars under different water regimes. Agricultural Water Management 99:103-110.

Dordas C (2009). Dry matter, nitrogen and phosphorus accumulation, partitioning and remobilization as affected by $\mathrm{N}$ and $\mathrm{P}$ fertilization and source-sink relations. European Journal of Agronomy 30:129-139.

Douglas MH, Smallfield BM, Wallace AR, McGimpsey JA (2014). Saffron (Crocus sativus L.): The effect of mother corm size on progeny multiplication, flower and stigma production. Scientia Horticulturae 166:50-58.

El-Hendawy SE, Abd El-Lattief EA, Ahmed MS, Schmidhalter U (2008). Irrigation rate and plant density effects on yield and water use efficiency of drip-irrigated corn. Agricultural Water Management 95:836-844.

Escribano J, Alonso G-L, Coca-Prados M, Fernández J-A (1996). Crocin, safranal and picrocrocin from saffron (Crocus sativus L.) inhibit the growth of human cancer cells in vitro. Cancer Letters 100:23-30.

Gresta F, Lombardo GM, Siracusa L, Ruberto G (2008). Effect of mother corm dimension and sowing time on stigma yield, daughter corms and qualitative aspects of saffron (Crocus sativus L.) in a Mediterranean environment. Journal of the Science of Food and Agriculture 88:1144-1150.

ISO/TS 3632-1/2 (2003). Technical specification. Crocus sativus L. Saffron. Ed. ISO, Geneva, Switzerland.

Kafi M, Rashed MH, Koocheki A, Mollafilabi A (2002). Saffron: Production technology and processing. Center of Excellence for Agronomy (Special Crops) Faculty of Agriculture, Ferdowsi University of Mashhad, Iran.

Khorramdel S, Eskandari Nasrabadi S, Mahmoodi G (2015). Evaluation of mother corm weights and foliar fertilizer levels on saffron (Crocus sativus L.) growth and yield components. Journal of Applied Research on Medicinal and Aromatic Plants 2:9-14.
Koocheki A, Rezvani Moghaddam P, Mollafilabi A, Seyyedi SM (2012). Effects of high corm planting density and applying manure on flower and corm yields of saffron (Crocus sativus L.). 4th International Saffron Symposium: Advanced in Saffron Biology Technology and Trade.

Koocheki A, Seyyedi SM (2015). Relationship between nitrogen and phosphorus use efficiency in saffron (Crocus sativus L.) as affected by mother corm size and fertilization. Industrial Crops and Products 71:128-137.

Koocheki A, Seyyedi SM, Gharaei S (2016). Evaluation of the effects of saffron-cumin intercropping on growth, quality and land equivalent ratio under semi-arid conditions. Scientia Horticulturae 201:190-198.

Koocheki A, Seyyedi SM, Jamshid Eyni M (2014). Irrigation levels and dense planting affect flower yield and phosphorus concentration of saffron corms under semi-arid region of Mashhad, Northeast Iran. Scientia Horticulturae 180:147-155.

Koocheki A, Siahmarguee A, Azizi G, Jahani M (2011). The effect of high density and depth of planting on agronomic characteristic of Saffron (Crocus sativus L.) and corms behavior. Journal of Agroecology 3:36-49.

Kumar R, Singh V, Devi K, Sharma M, Singh MK, Ahuja PS (2009). State of art of saffron (Crocus sativus L.) agronomy: a comprehensive review. Food Reviews International 25:44-85.

Lage M, Cantrell CL (2009). Quantification of saffron (Crocus sativus L.) metabolites crocins, picrocrocin and safranal for quality determination of the spice grown under different environmental Moroccan conditions. Scientia Horticulturae 121:366-373.

Lea PJ, Azevedo RA (2006). Nitrogen use efficiency. 1. Uptake of nitrogen from the soil. Annals of Applied Biology 149:243-247.

Maleki M, Ebrahimzade H, Gholami M, Niknam V (2011). The effect of drought stress and exogenous abscisic acid on growth, protein content and antioxidative enzyme activity in saffron (Crocus sativus L.). African Journal of Biotechnology 10:90689075.

Motalebifard R, Najafi N, Oustan S, Nyshabouri MR, Valizadeh M (2013). The combined effects of phosphorus and zinc on evapotranspiration, leaf water potential, water use efficiency and tuber attributes of potato under water deficit conditions. Scientia Horticulturae 162:31-38.

Omidi H, Naghdibadi HA, Golzad A, Torabi H, Fotoukian MH (2009). The effect of chemical and bio-fertilizer source of nitrogen on qualitative and quantitative yield of saffron (Crocus sativus L.). Journal of Medicinal Plants 8:98-109.

Ourry A, Boucaud J, Salette J (1988). Nitrogen mobilization from stubble and roots during re-growth of defoliated perennial ryegrass. Journal of Experimental Botany 39:803-809.

Reddy AR, Chaitanya KV, Vivekanandan M (2004). Droughtinduced responses of photosynthesis and antioxidant metabolism in higher plants. Journal of Plant Physiology 161:1189-1202.

Renau-Morata B, Nebauer SG, Sánchez M, Molina RV (2012). Effect of corm size, water stress and cultivation conditions on photosynthesis and biomass partitioning during the vegetative growth of saffron (Crocus sativus L.). Industrial Crops and Products 39:40-46. 
Salvagiotti F, Castellarín JM, Miralles DJ, Pedrol HM (2009). Sulfur fertilization improves nitrogen use efficiency in wheat by increasing nitrogen uptake. Field Crops Research 113:170-177.

Sani BM, Oluwasemire KO, Mohammed HI (2008). Effect of irrigation and plant density on the growth, yield and water use efficiency of early maize in the Nigerian Savanna. Journal of Agricultural and Biological Science 3:33-39.

SAS (2011). SAS for Windows Version 9.3. SAS Institute Inc, Cary, NC, USA.

Sepaskhah AR, Kamgar-Haghighi AA (2009). Saffron irrigation regime. International Journal of Plant Production 3:1-16.

Sepaskhah AR, Yarami N (2009). Interaction effects of irrigation regime and salinity on flower yield and growth of saffron. The Journal of Horticultural Science and Biotechnology 84:216-222.

Singh-Sangwan N, Abad Farooqi AH, Sangwan RS (1994). Effect of drought stress on growth and essential oil metabolism in lemongrasses. New Phytologist 128:173-179.

Srivastava R, Ahmed H, Dixit RK, Dharamveer, Saraf SA (2010). Crocus sativus L.: A comprehensive review. Pharmacognosy Reviews 4:200-208.

Stroosnijder L, Moore D, Alharbi A, Argaman E, Biazin B, van den Elsen E (2012). Improving water use efficiency in drylands. Current Opinion in Environmental Sustainability 4:497-506.
Talaei A, Hassanpour Moghadam M, Sajadi Tabassi SA, Mohajeri SA (2015). Crocin, the main active saffron constituent, as an adjunctive treatment in major depressive disorder: A randomized, double-blind, placebo-controlled, pilot clinical trial. Journal of Affective Disorders 174:51-56.

Tamaddonfard E, Farshid AA, Maroufi S, Kazemi-Shojaei S, Erfanparast A, Asri-Rezaei S, Taati M, Dabbaghi M, Escort M (2014). Effects of safranal, a constituent of saffron, and vitamin $\mathrm{E}$ on nerve functions and histopathology following crush injury of sciatic nerve in rats. Phytomedicine 21:717-723.

Tarantilis PA, Tsoupras G, Polissiou M (1995). Determination of saffron (Crocus sativus L.) components in crude plant extract using high-performance liquid chromatography-UV-visible photodiode-array detection-mass spectrometry. Journal of Chromatography A 699:107-118.

Yarami N, Kamgar-Haghighi AA, Sepaskhah AR, Zand-Parsa S (2011). Determination of the potential evapotranspiration and crop coefficient for saffron using a water-balance lysimeter. Archives of Agronomy and Soil Science 57:727-740.

Yarami N, Sepaskhah AR (2015). Saffron response to irrigation water salinity, cow manure and planting method. Agricultural Water Management 150:57-66. 